\title{
Risk factors related to antisocial behavior in teenagers with intellectual disabilities
}

\author{
Pavel A. Kislyakov \\ Department of Psychology of Labor and Psychology of Special Needs, Russian State Social \\ University, Moscow, Russia
}

Corresponding author. E-mail: pack.81@mail.ru

Background. Throughout the ontogenic development period and life journey, everyone faces numerous threats and challenges. Certain of these challenges are beyond the individual's control and are caused by social and environmental factors, but others, conversely, are provoked by the individual's own lifestyle and mental and/or physical health condition. This paper considers how the social adaptation of children with intellectual developmental disorders affects the development of various forms of socially dangerous behavior.

Objective. The primary goal of the study described in the article is to identify and analyze the potential risk factors related to antisocial behavior among teenagers with intellectual disabilities (mental retardation) based on a survey of teachers in special (correctional) schools.

The methodological basis of our research uses the provisions of Lev Vygotsky's theory of socialization among children with intellectual disabilities. This article shows the importance of implementing Lev Vygotsky's doctrine of correction and compensation of disturbed psychological, emotional and social development of schoolchildren with intellectual disabilities.

Design. To achieve this purpose, the following methods were used: interviews, questionnaires, and factor analysis. In the first stage of the study, interviews were conducted with teachers working in special (correctional) schools (teachers, child and youth counselors, school psychologists, developmental pediatricians) - of 108 teachers from 10 schools. Analysis of the interviews revealed a list of risk factors related to antisocial behavior among teenagers with intellectual disabilities (only 35 points). The collected data formed the basis for a questionnaire, "Social Safety for Children with Intellectual Disabilities". In the second stage, 83 teachers working in the special (correctional) schools were surveyed. The survey was completed by teachers of children (12-13 years old) who had a diagnosis of F70 (Mild mental retardation) or F71 (Moderate mental retardation). To determine the significance of risk factors, the respondents were asked to assess children's exposure to risk factors on a 5-point scale. In the third stage, the results of the risk factor assessment conducted in relation to socially dangerous behavior of adolescents with intellectual disabilities were processed using the factor analysis. 
Results. From the factor analysis of the data collected, as well as an analysis of the relevant theoretical and methodological materials, the following risk factors (with load factors) of socially dangerous behavior among teenagers with intellectual disabilities were identified: antisocial behavior (violation of generally accepted societal norms) (48.7\%); asociality (the lack of motivation to engage in social interaction) (7.96\%); infantilism (5.9\%); social mistrust in the world (4.86\%); propensity for victimizing behavior (4.18\%); virtual addiction (3.98\%); and high self-concept discrepancies (3.14\%).

Conclusions. The results of our research may be used to prevent antisocial behavior in teenagers with intellectual disabilities through the implementation of psychological and pedagogical follow-up programs aimed at preventing antisocial and asocial behavior, overcoming infantilism and victimization, forming adequate self-esteem, and forming personality-trusting relationships with significant adults and peers.

Keywords: intellectual disabilities, teenagers, socialization, social safety, risk factors, antisocial behavior, psychological and pedagogical support

\section{Introduction}

Recently, a key element of public policy in many countries has been social policy relating to disabled people. Among other things, a primary focus is on providing equal opportunities for a healthy and safe life for everyone, including disabled people and people with health conditions. Social institutions face the challenge of creating the specific conditions that ensure access to health improvement, rehabilitation, social adaptation, education and employment for disabled people and people with health conditions. Achieving this objective should be the primary goal of institutions of education, culture, sports and health care.

One of the most numerous groups of children with health conditions (or special educational needs) includes children with intellectual developmental disorders: children with intellectual disabilities (mental retardation) and children with developmental delay. According to different estimates, the number of children with intellectual development disorders has risen dramatically in recent years, ranging between $5 \%$ and $10 \%$ of the total child population. In persons with intellectual disabilities, the central nervous system cannot ensure the foundation required for the development of personality but instead creates obstacles that restrict the child's understanding of and conscious attention toward reality, which is the most important prerequisite for the social and psychological safety and welfare of the child. Deficits in general intellectual functioning that adversely affect the social relations of a child with a mental development disorder hinder the child's cognitive development and social integration and adaptation (Ainsworth, 2004; Harvey, 2006; Santo \& Buono, 2006; Shmeleva, Pravdov, Kislyakov, \& Kornev 2016; Speck, 1999). Vygotsky's (1983) suggestion that we consider the problem of intellectual disability in children as not only a psychological and pedagogical problem but also a social one remains relevant today.

Having left school (typically a special education school), an individual with intellectual development disorder should become a member of society and be ready to live in social environment that is not always supportive but sometimes insecure. Many years of experience in special (corrective) education shows that 
when given proper education, training and relevant preparation for future labor activities, the overwhelming majority of intellectually disabled children are, by the age of 15 to 20 , able to adapt socially to such an extent that they are almost indistinguishable in everyday life from typically developing individuals (Speck, 1999; Vygotsky, 1983). However, to date, insufficient consideration has been given to ensuring appropriate conditions for the formation of psychological preparedness of intellectually disabled children for overcoming their social communication difficulties, which significantly complicates their further social adaptation and integration.

Throughout the ontogenic development period and life journey, everyone faces numerous threats and challenges. Certain of these challenges are beyond the individual's control and are caused by social and environmental factors, but others, conversely, are provoked by the individual's own lifestyle and mental and/or physical health condition. Any deviations in the development of a child's personality involve real and potential risk factors that affect his/her physical and psychosocial security and cause socialization problems. This phenomenon is observed because the development of a child suffering from intellectual disability occurs in such a way that the child's natural psychical functions - e.g., sensibility, emotional reactivity, and memory - do not transform into sophisticated cultural "mechanisms" of reality reflection (Vygotsky, 1983). A intellectually disabled child's becoming acquainted with various objects and phenomena in the world around him/her occurs rather superficially and fragmentally, sometimes with distorted perception. For this reason, it is difficult for such a child to follow the rules of safe conduct in various spheres of life and to adequately assess social situations involving risk. Children with intellectual disabilities have specific disorders of their mental development: underdevelopment of cognitive processes, unstructured thinking, semantic and associative memory disorders, speech underdevelopment, a lack of attention, disorders in emotional and volitional sphere, as well as behavior disorders. Accordingly, it is difficult for such a child to understand life situations and to behave safely (Davydova, 2009; Fatikhova \& Sayfutdiyarova, 2016; Katzl \& Singh, 1986). The fragility of the child's psychological defense mechanisms degrades his/her adaptive capabilities (Kolosova, 2007). A intellectually disabled child's disorientation in the surrounding world can lead to unsafe behavior (e.g., victimizing, addictive, delinquent, aggressive behavior, risky behavior). Vygotsky (1983) noted that certain social changes in personality development occur synchronously with corresponding biological shifts. Therefore, if the conditions conducive to the comprehensive development of the child are not established - for instance, if certain personal qualities are not intentionally developed and patterns of safe, defensive and coping behavior are not formed - the child's life is unlikely to be successful (Epstein, 1992; Kolosova, 2007; Nakano, 1991). A multi-aspect approach to security considers security to be a condition that enables the fundamental securitization of personality. This approach therefore makes it possible to consider the condition of personality security a social and normative ideal (Zinchenko, 2011b).

Children with intellectual disabilities, similar to typically developing children, experience the crisis of adolescence and puberty changes. One of the most 
common characteristics of the period of adolescence is emotional instability. As Vygotsky (1984) wrote, a teenager's personality structure has nothing stable, completed or rigid. Such emotional instability manifests primarily as mood swings and floating affect (i.e., the emotional lability associated with puberty and the age-related physical changes that adolescents undergo). This personal instability gives rise to conflicting desires and conflicting actions. The teenage years are characterized by moral instability. Teenagers need close friends and seek relational tribes among their peers. These tribes often dictate much of the teen's discretionary time. Following his/her peers' way of viewing and interacting with the surrounding world, a teenager often becomes a conformist. Sometimes, under the influence of their friends or tribes, teenagers do things that they would not otherwise do and may sincerely regret their actions later. Furthermore, the teenage years are characterized by instability of self-esteem (Davey, Eaker, \& Walters, 2003). Both teenagers' behavior and their self-consciousness are highly dependent on external influences (De Man \& Gutierrez, 2002). Anna Freud (1936) wrote about the time of adolescence: adolescents are excessively egoistic, regarding themselves as the center of the universe and the sole object of interest; however, at no time in later life are they capable of the degree of self-sacrifice and devotion they show in adolescence.

Adolescence is often called a protracted crisis characterized by the manifestation of severe social problems in behavior, such as running away from home; school failures and dropouts; violations of school rules and rules of conduct in public places; alcohol, drug and tobacco use; theft, suicidal behavior; and sexual deviations (Davey et al., 2003; Lewinsohn, Rohde, \& Seeley, 1994). In addition, all too often, adolescents commit gang crimes.

Following Zinchenko (2011a), we use the cultural-historical psychology of Vygotsky as a general methodological basis for the analysis of issues of human security. The child perceives his/her safety or vulnerability in an environment (and in a particular situation). Vygotsky (1983) described the "social situation of development" as the relationship existing between a child and its social environment. According to Vygotsky (1983), social surroundings are a source of development. The social situation of development (e.g., cultural and historical) influences the formation of the individual characteristics that contribute to the development of an antisocial versus prosocial personality (Zinchenko, 2011b). The modern social environment is increasingly characterized as a "risky society" (in the words of Ulrich Beck). The primary local social risks that negatively affect the development of educated and healthy children are social risks in the educational environment (dehumanization and an increase in violence, intensification of the educational process, pedagogical tactics that create stress in students); factors caused by students' staying in a socially risky group (informal youth groups, destructive religious organizations); and negative behavioral characteristics of young people (deviant, addictive, victim-like, antisocial) (Kislyakov, Shmeleva, \& Silaeva, 2017; Shmeleva, Kislyakov, Luneva, \& Maltseva, 2015).

Because students increasingly spend more time in school than in their family environment, it is difficult to overestimate the degree of influence of the school "microcosm" on the social integration, development, health and behavior of a child or teenager. The characteristics of the educational institution can be considered 
environmental factors that determine the psychosocial prosperity (security) of students (Baeva \& Bordovskaia, 2015; Kislyakov, Shmeleva, Belyakova, \& Romanova, 2016; Noddings, 2003; Suldo, Shaffer, \& Riley, 2008).

Vygotsky (1983) stated that an individual's social surroundings (primarily the educational environment) could contribute to complex types of psychic activity, "psychological functions," in children with intellectual disabilities. The educational environment should contribute to the development of adaptive behavior of children. Adaptive behavior includes the age-appropriate behaviors necessary for people to live independently and to function safely and appropriately in daily life. The system of social and psychological security of children with intellectual disabilities must address several related areas. The first is to create a safe social environment. The second is to teach safety rules and life skills. The third is to mitigate risk factors related to antisocial behavior.

\section{Method}

To identify the risk factors related to dangerous behavior in adolescents with intellectual disabilities, we consulted educators (teachers, child and youth counsellors, school psychologists, and developmental pediatricians) in the Ivanovo region and in the city of Moscow. The study involved three stages: interviews with teachers, questionnaires given to teachers, and factor analysis of the risk factors identified in the first two stages.

In the first stage of the study, interviews were conducted with 108 educators working in 10 different special (correctional) schools. Processing the interviews revealed a list of risk factors related to antisocial behavior among teenagers with intellectual disabilities ( 35 items). The collected data formed the basis for a questionnaire "Social Safety for Children with Intellectual Disabilities." When designing the questionnaire, we intended to collect information on risk factors related to socially dangerous behavior of schoolchildren with intellectual disabilities affecting both the schoolchildren themselves and their peers (that is, behavior posing a danger to themselves and to others).

In the second stage, 83 teachers working in special (correctional) schools were given the questionnaire developed in the first stage. The questionnaire was completed by teachers of children (12-13 years old) who had a diagnosis of F70 (Mild mental retardation) or F71 (Moderate mental retardation). To define the significance of each risk factor, the respondents were asked to assess how likely students were to experience each risk on a 5-point scale from 1 (student is unlikely to experience this risk) to, 5 (very likely to experience this risk).

In the third stage, a factor analysis was conducted on the results of the questionnaire to determine critical risk factors related to socially dangerous behavior in adolescents with intellectual disabilities.

\section{Results}

The results of the survey showed that all of the risk factors were somewhat likely to be experienced by youngsters. Figure 1 shows an analysis of the results of the survey of teachers (arithmetic mean scores). 


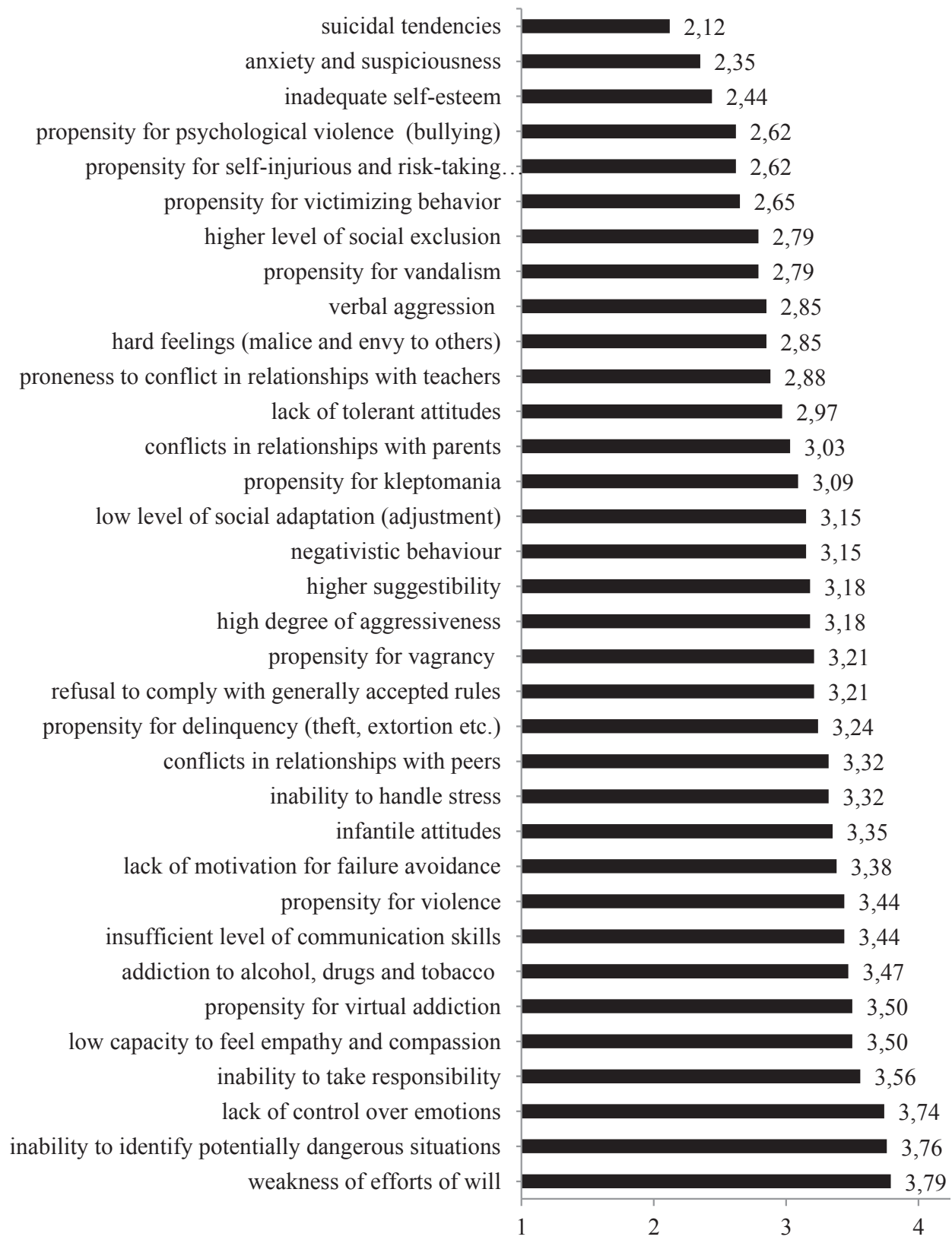

Figure 1. Assessment of risk factors related to dangerous behavior in adolescents with intellectual disabilities according to the results of a survey of educators. The average likelihood of experiencing each risk factor is represented on a scale from 1 (does not correspond completely) to 5 (corresponds completely). 
The leading risk factors identified are noted below:

- low threat sensitivity (inability to identify potentially dangerous situations);

- propensity for virtual addiction (computer and Internet addiction, video game addiction, gadget addiction);

- involuntary emotional displays of mood (destructiveness);

- inability to take responsibility;

- poor/insufficient willpower;

- insufficient level of communication skills;

- low capacity to feel empathy and compassion, or to render assistance;

- inadequate self-esteem.

The results of the assessment of risk factors related to socially dangerous behavior in adolescents with intellectual disabilities were processed using a factor analysis (using Varimax rotation with Kaiser Normalization) in the standardized software package SPSS 22. The contents and percentage of the risk factors are shown in Table 1.

The cumulative percentage (which indicates the informativeness of all factors) constitutes $78.73 \%$, which is an acceptable result. This finding is an important indication that the risk factors in question can represent this set of characteristics. The result shows the internal consistency of the factor structure and can be interpreted as a tool for the explanation of empirical regularities. When interpreting the factors, we only considered those with factor loadings exceeding 0.5 .

\section{Discussion}

The following refers to the factors presented in Table 1 .

The first factor is a factor of major importance. It can be defined as socially dangerous (antisocial) behavior characterized by negativism toward generally accepted rules, a higher propensity for delinquency, vandalism, and vagrancy, the use of psychoactive substances, unreasonable risk-taking along with negativistic behavior and desire to hurt anyone or anything.

The second factor reflects asociality (social indifference) of adolescents with intellectual disabilities. Asociality comprises their lack of motivation to engage in social interaction and to avoid failure, low capacity to feel empathy and compassion, unwillingness to render assistance, a lack of tolerant attitudes, and poor communication skills. Failure to communicate effectively often leads to conflict with adults (for instance, with teachers). Such teenagers also have disturbances in social perception (identification, empathy) and are therefore not very sensitive to threats coming from other people.

The third factor reveals infantilism of adolescents with intellectual disabilities, that is, their social immaturity, characterized by retardation in their personality development. The primary factors influencing the formation of infantilism in adolescents with intellectual disabilities are a lack of cognitive interests or a steady decline in cognitive abilities and a lack of initiative, necessary social skills and independence. Their communication skills are developed insufficiently, mental activity 
Table 1. Structure of risk factors related to dangerous behavior in adolescents with intellectual disabilities (according to the results of the survey of educators)

\begin{tabular}{|c|c|c|c|}
\hline $\begin{array}{l}\text { Num- } \\
\text { ber of } \\
\text { factor }\end{array}$ & $\begin{array}{c}\text { Specific } \\
\text { weight of } \\
\text { factor }(\%)\end{array}$ & Risk factors & $\begin{array}{l}\text { Factor } \\
\text { name }\end{array}$ \\
\hline 1 & 48.7 & $\begin{array}{l}\text { Refusal to comply with generally accepted rules and to } \\
\text { adopt universal values }(0.849) \\
\text { Addiction to alcohol, drugs and tobacco }(0.837) \\
\text { Propensity for delinquency (e.g., theft, extortion) (0.714) } \\
\text { A high degree of aggressiveness }(0.674) \\
\text { Propensity for kleptomania ( } 0.673) \\
\text { Propensity for vagrancy }(0.629) \\
\text { Inability to handle stress }(0.588) \\
\text { Negativistic behavior }(0.500) \\
\text { Propensity for vandalism (0.533) } \\
\text { Propensity for self-injurious and risk-taking behavior } \\
\text { (thrill-seeking, e.g., parkour, train surfing) (0.532) }\end{array}$ & $\begin{array}{l}\text { Socially } \\
\text { dangerous } \\
\text { (antisocial) } \\
\text { behavior }\end{array}$ \\
\hline 2 & 7.96 & $\begin{array}{l}\text { Low capacity to feel empathy and compassion }(0.772) \\
\text { Lack of motivation for failure avoidance }(0.762) \\
\text { Inability to identify potentially dangerous situations }(0.749) \\
\text { Lack of tolerant attitudes }(0.748) \\
\text { Insufficient level of communication skills }(0.602) \\
\text { Proneness to conflict in relationships with teachers }(0.596)\end{array}$ & $\begin{array}{l}\text { Asociality } \\
\text { (social in- } \\
\text { difference) }\end{array}$ \\
\hline 3 & 5.9 & $\begin{array}{l}\text { Lack of control over emotions }(0.777) \\
\text { Higher suggestibility }(0.724) \\
\text { Propensity for delinquency (theft, extortion, etc.) (0.694) } \\
\text { Infantile attitudes }(0.565)\end{array}$ & Infantilism \\
\hline 4 & 4.86 & $\begin{array}{l}\text { Hard feelings (malice toward and envy of others) }(0.775) \\
\text { Anxiety and suspiciousness (ranging from mistrust and } \\
\text { prudence in relation to other people to conviction that } \\
\text { other people always try to do harm) (0.690) } \\
\text { Weakness of efforts of will ( } 0.643) \\
\text { Inability to take responsibility (0.642) } \\
\text { Propensity for psychological violence (bullying) (0.568) } \\
\text { Verbal aggression (0.552) } \\
\text { Low level of social adaptation (adjustment) (0.523) }\end{array}$ & $\begin{array}{l}\text { Social } \\
\text { mistrust in } \\
\text { the world }\end{array}$ \\
\hline 5 & 4.18 & $\begin{array}{l}\text { Conflicts in relationships with parents }(0.625) \\
\text { Propensity for victimizing behavior }(0.607)\end{array}$ & $\begin{array}{l}\text { Victimizing } \\
\text { behavior }\end{array}$ \\
\hline 6 & 3.98 & $\begin{array}{l}\text { Propensity for virtual addiction }(0.796) \\
\text { Conflicts in relationships with peers }(0.508)\end{array}$ & $\begin{array}{l}\text { Virtual } \\
\text { addiction }\end{array}$ \\
\hline 7 & 3.14 & $\begin{array}{l}\text { Inadequate self-esteem }(0.842) \\
\text { Higher level of social exclusion }(0.592)\end{array}$ & $\begin{array}{l}\text { Inadequate } \\
\text { self-esteem }\end{array}$ \\
\hline
\end{tabular}


is disturbed (leading to impulsivity, emotional instability, affectability), moral and social maturation is retarded; they place a priority on the satisfaction of their own needs for entertainment and enjoyment. Such infantilism is indicative of a dependent and subservient personality. A teenager with intellectual disability becomes unexacting, often gullible and credulous, amenable to persuasion by authoritarian personalities, which can lead to the individual being induced to commit criminal offences (e.g., theft and extortion).

The fourth factor represents a personality trait of a teenager with intellectual disability that can be characterized as "social mistrust in the world." Vygotsky (1983) emphasized the role of adults in the cognitive development of a child. Vygotsky observed that children develop and learn cognitive tasks only through their interactions with older peers and adults, with affective reactions and speech playing the fundamental role. Trust in the world is a particular phenomenon that consists of the specific attitude of an individual toward various objects or fragments of the world, which includes the individual's perception of continuing relevance and a priori safety of these objects or fragments of the world for himself/herself (Simpson, 2007; Dontsov, Zinchenko, Zotova, \& Perelygina, 2015). Basic mistrust, then, is a general sense of insecurity of the surrounding world. The desire to avoid any unwanted impacts of the social environment appears at early stages of ontogenesis as a logical result of the basic trust with which a child is born (according to Erikson, 1963). If the crisis of "basic trust/mistrust" is not resolved in a timely and adequate manner, it can affect an individual in the future, taking the form of social mistrust in himself/herself, in other people or in the world (Kjærnes, 2006). The most significant signs of mistrust are immorality, unreliability, destructiveness, membership in a hostile social group, susceptibility to conflict, impoliteness, and withdrawn behavior, which almost inevitably entail a lack of initiative or a sense of responsibility, as well as the occurrence of feelings of injury, frustration and suspiciousness. Such social mistrust in the world can be followed by malice, fantasies about destruction and vandalism. A teenager's lack of trust can result in his/her social isolation, emotional withdrawal, and therefore result in poor willpower and a low level of social adaptation. The adolescents who mistrust the world around them are not able to build trust-based relationships with other people, or to be flawed. Social mistrust in the world may be manifested in overt behavior via verbal aggression and bullying.

The fifth factor shows the propensity of adolescents with intellectual disabilities for victimizing behavior (that is, engaging in behavior of a potential "victim," provoking other people's aggression against him/her). Intellectually disabled children have extremely suggestible and less cautious personalities compared to their typically developing peers. According to the classification suggested by Hans von Hentig (1979), adolescents with intellectual disabilities could be included in the "The Young" and "The Mentally Defective and Deranged" typology of crime victims, depending on their specific propensity for victimizing behavior.

The sixth factor shows the inclination of adolescents with intellectual disabilities to virtual addiction (video game addiction, gadget addiction) and their susceptibility to conflict and inability to build and maintain constructive relationships with their peers. Real life then becomes a series of problems for many of these adolescents, and they try to escape from reality by immersing themselves 
in the virtual world of computer games and social networks. This world enables a young gamer to feel "strong," "self-confident," a "winner," and furthermore, it allows him/her to correct mistakes and failure as many times as he/she wants, removing the responsibility for incorrect decisions and helping him/her disregard problems. A teenager's passion for computer games may be, in certain respects, a sign of personal troubles. Prevalently, video game addiction is highly common in those teenagers who cannot successfully assert themselves in other activities (Gackenbach, 2006; Mazalin \& Moore, 2004; Soldatova \& Zotova, 2012). Adolescents with intellectual disabilities constitute a particular risk group in this area. The virtual environment is perceived by children with intellectual disabilities through intellectual and emotional structures that are not only immature but also defective, which leads to disorders of socialization and the occurrence of addictive behaviors (Minyakina, 2008).

The seventh factor reflects the inadequate self-esteem of adolescents with intellectual disabilities and their social isolation. In his research, Vygotsky (1983) noted that adolescents with intellectual disabilities have inflated self-appraisal and are rarely dissatisfied with themselves. Such overestimation of their own capacities results in overconfidence followed by inadequate apprehension of potential dangers and an inability to evaluate the reasonableness of their actions and to foresee the consequences thereof. Self-esteem allows children to regulate their own behavior and to self-monitor in their social interaction. The level of self-esteem formation in adolescence is an important factor in the development of the communication skills of a person. Furthermore, self-esteem affects the interpretation of the results of both socialization and social adaptation as a whole (Webster \& Sobieszek, 1974).

\section{Conclusion}

Numerous research works carried out in Russia and abroad support Vygotsky's idea that the development of a child with intellectual disabilities requires particular guidance by adults (e.g., teachers, psychologists, special-needs experts). The risk factors described above must be taken into consideration when planning psychological and pedagogical support for the protection and social security of adolescents with intellectual disabilities. The support must be aimed at preventing of antisocial and asocial behavior, overcoming infantilism and victimization, helping the formation of an adequate self-esteem, and helping the formation of personality-trusting relationships with significant adults and peers. It is necessary to note the hierarchy of the significant risk factors related to antisocial behavior among teenagers with intellectual disabilities because every subsequent factor, to a certain degree, depends on and is related to the previous one. For instance, the prevention of antisocial and asocial behavior is not possible without overcoming infantilism and establishing personality-trusting relationships.

The successful solution to this challenge will only be possible if children live in a safe and protective environment. Any educational organization or social institution where formation of the child's personality occurs must create stable environment, use technologies that pose little or no risk to children and ensure their resilience to potential negative impacts of the social environment. An important component of the program for the prevention of socially dangerous behavior in adolescence is 
protection from or mitigation of social or social-psychological threats. This component ensures that adolescents feel psychologically and socially safe and secure, encourages them to conform to standards of appropriate behavior that does not encroach on the freedom, dignity, or physical safety of other people, stimulates their social activity and promotes the development of personality.

\section{Acknowledgments}

The publication was prepared within the framework of a research project supported by the Russian Foundation for Fundamental Research (grant No. 16-36-01088 "Socio-psychological safety of children with intellectual disabilities in a metropolis"). The author is grateful to Olga Silayeva, Vasiliy Feofanov, and Aleksey Udodov for assistance in the collection of empirical data.

\section{References}

Ainsworth, P. (2004). Understanding Mental Retardation. Jackson: University Press of Mississippi.

Baeva, I.A., \& Bordovskaia N. V. (2015). The psychological safety of the educational environment and the psychological well-being of Russian secondary school pupils and teachers. Psychology in Russia: State of the Art, 8(1), 86-99. doi: 10.11621/pir.2015.0108.

Davey, M., Eaker, D.G., \& Walters, L.H. (2003). Resilience processes in adolescents: Personality profiles, self-worth and coping. Journal of Adolescent Research, 18(4), 347-362. doi: $10.1177 / 0743558403018004002$

Davydova, M.S. (2009). Osobennosti formirovaniya sotsialnykh predstavleniy o bezopasnosti zhiznedeyatelnosti u detey s intellektualnymi narusheniyami [Peculiarities of forming of social notions about vital safety among children with mental disturbances]. Izvestiya Rossiyskogo gosudarstvennogo pedagogicheskogo universiteta im. A. I. Gertsena [Izvestia: Herzen University Journal of Humanities \& Sciences], 98, 94-101.

De Man, A.F., \& Gutierrez, B.I. (2002). The relationship between level of self-esteem and suicidal ideation with stability of self-esteem as moderator. Canadian Journal of Behavioral Science, 34(4), 235-238. doi: 10.1037/h0087176

Dontsov, A.I., Zinchenko, Yu.P., Zotova, O.Yu., \& Perelygina, E.B. (2015). Psikhologiya bezopasnosti [Psychology of security]. Moscow: Yurayt.

Epstein, S. (1992). Coping ability, stress, productive load, and symptoms. Journal of Personality and Social Psychology, 62(5), 813-825. doi: 10.1037/0022-3514.62.5.813

Erikson, E. (1963). Child and society. New York: W.W. Norton.

Fatikhova L.F., \& Sayfutdiyarova, E.F. (2016). Understanding of unsafe situations by children with intellectual disabilities. Psychology in Russia: State of the Art, 9(4), 138-151. doi: 10.11621/pir.2016.0411

Freud, A. (1936). Das Ich und die Abwehrmechanismen. Wien: Internationaler Psychoanalytischer Verlag.

Gackenbach, J. (Ed.) (2006). Psychology and the Internet: Intrapersonal, interpersonal and transpersonal implications. San Diego, CA: Academic Press.

Switzky, H.N. (2006). The importance of cognitive-motivational variables in understanding the outcome performance of persons with mental retardation: A personal view from the early twenty-first century international. Review of Research in Mental Retardation, 31, 1-29. doi: 10.1016/S0074-7750(05)31001-9 
von Hentig, H. (1979). The criminal and his victim: Studies in the sociobiology of crime. New York: Schoc ken Books.

Simpson, J.A. (2007). Psychological foundations of trust. Current Directions in Psychological Science, 16(5), 264-268. doi:10.1111/j.1467-8721.2007.00517.x

Katz, R.C., \& Singh, N.N. (1986). Comprehensive fire-safety training for adult intellectually disabled persons. Journal of Intellectual Disability Research, 30(1), 59-69. doi:10.1111/j.13652788.1986.tb01298.x

Kislyakov, P.A., Shmeleva, E.A., Belyakova, N.V., \& Romanova, A.V. (2016). Threats to the social safety of educational environment in the Russian schools. Ponte, 72(12), 355-363. doi:10.21506/j.ponte.2016.12.28.

Kislyakov, P., Shmeleva, E., \& Silaeva, O. (2017). The contemporary threats and how to prevent them in the social-psychological safety of an educational environment. In D. E. Pinn (Ed.), Environmental education: Perspectives, challenges and opportunities (pp. 85-100). New York: Nova Science Publishers, Inc.

Kjærnes, U. (2006). Trust and distrust: Cognitive decisions or social relations? Journal of Risk Research, 9(8), 911-932. doi: 10.1080/13669870601065577

Kolosova, T.A. (2007). Osobennosti koping-povedeniya i mekhanizmov psikhologicheskoy zashchity umstvenno otstalykh podrostkov [Peculiarities of coping behavior and mechanisms of psychological protection of intellectually disabled teenagers]. Izvestiya Rossiyskogo gosudarstvennogo pedagogicheskogo universiteta im. A. I. Gertsena [Izvestia: Herzen University Journal of Humanities \& Sciences], 10(31), 189-194.

Lewinsohn, P.M., Rohde, P., \& Seeley, J.R. (1994). Psychological risk factors for future adolescent suicide attempts. Journal of Consulting and Clinical Psychology, 62(2), 297-305. doi: 10.1037/0022-006X.62.2.297

Mazalin, D., \& Moore, S. (2004). Internet use, identity development and social anxiety among young adults. Behavior Change, 21, 90-102. doi: 10.1375/bech.21.2.90.55425

Minyakina, Y.V. (2008). Psikhoprofilaktika igrovoy zavisimosti (gemblinga) u detey s umstvennoy otstalostyu [Psycho-prophylaxis of gambling in children with mental retardation]. Spetsialnoe obrazovanie [Special education], 10, 52-54.

Nakano, K. (1991). The role of coping strategies on psychological and physical well-being. Journal of Psychological Research, 33(4), 160-167.

Noddings, N. (2003). Happiness and education. New York: Cambridge University Press. doi: $10.1017 / \mathrm{CBO} 9780511499920$

Di Nuovo, S.F., \& Buono, S. (2006) Psychiatric syndromes comorbid with mental retardation: Differences in cognitive and adaptive skills. Journal of Psychiatric Research, 41(9), 795-800.

Shmeleva, E.A., Kislyakov, P.A., Luneva, L.F., \& Maltseva, L.D. (2015). Psychological factors of the readiness of teachers to ensure social security in the educational environment. Psychology in Russia: State of the Art, 8(1), 74-85. doi: 10.11621/pir.2015.0107

Shmeleva, E.A., Pravdov, M.A., Kislyakov, P.A., \& Kornev, A.V. (2016). Psikhologo-pedagogicheskoe soprovozhdenie razvitiya i korrektsii psikhofunktsionalnykh i fizicheskikh sposobnostey $\mathrm{v}$ protsesse sotsializatsii detey s intellektualnoy nedostatochnostyu [Psycho-pedagogical support of development and correction of psycho-functional and physical abilities within socialization of intellectually disabled children]. Teoriya i praktika fizicheskoy kultury [Theory and Practice of Physical Culture], 3, 41-43.

Soldatova, G., \& Zotova, E. (2012). Coping with online risks: The experience of Russian schoolchildren. Journal of Children and Media, 6(11), 44-59. doi:10.1080/17482798.2012.739766

Speck, O. (1999). Menschen mit geistiger Behinderung und ihre Erziehung: Ein heilpädagogisches Lehrbuch (9. überarb Aufl). München; Basel: E. Reinhardt. 
Suldo, S., Shaffer, E., \& Riley, K. (2008). A social-cognitive-behavioral model of academic predictors of adolescents' live satisfaction. School Psychology Quarterly, 23, 56-69. doi: 10.1037/1045-3830.23.1.56

Vygotsky, L.S. (1983). Sobranie sochineniy v 6 T. T. 5. Osnovy defektologii [Collected works in 6 volumes. Vol. 5. Basics of Defectology] Moscow: Pedagogy.

Vygotsky, L.S. (1984). Sobranie sochineniy v 6 T. T. 4. Detskaya psikhologiya [Collected works in 6 volumes. Vol. 4. Child psychology]. Moscow: Pedagogy.

Webster, M., \& Sobieszek, B. (1974). Sources of self-evaluation. A formal theory of significant others and social influence. New York: Wiley.

Zinchenko, Yu.P. (2011a). Metodologicheskie osnovy psikhologii bezopasnosti [Methodological bases of security psychology]. Natsionalnyy psikhologicheskiy zhurnal [National Psychological Journal], 2, 11-14.

Zinchenko, Yu.P. (2011b) Security psychology as social systemic phenomenon. Psychology in Russia: State of the Art, 4, 305-315. doi: 10.11621/pir.2011.0019

Original manuscript received June 17, 2016

Revised manuscript accepted December 21, 2016

First published online June 30, 2017 